UDC: 351.78(497.1 Dunavska banovina)

Предраг М. Вајагић

Универзитет у Новом Саду

Филозофски факултет

Докторанд

pedja1975@gmail.com
Оригиналан научни рад

примљено: 27. март 2013

прихваћено: 1. октобар 2013

\title{
ОРГАНИ БЕЗБЕДНОСТИ НА ТЕРИТОРИЈИ ДУНАВСКЕ БАНОВИНЕ
}

Сажетак: У раду се разматра организација безбедоносног система на територији Дунавске бановине, преко ког се може стећи увид у његово стање на територији целе Краљевне Југославије. Посебан осврт је дат на однос који су припадници органа безбедности имали према грађанима и припадницима националних мањина. Вршење њихове службе великим делом било је условљено притисцима, којима су и сами били изложени од стране централних управних органа. Коришћен је фонд Краљевске банске управе Дунавске бановине Архива Војводине, као и Службене новине Краљевине Југославије.

Кључне речи: јавна безбедност, организација полицијских установа, полицијски службеници, предстојништва градске полиције, полицијска служба, безбедоносна ситуација, жандармерија, полицијска репресија.

После десет година постојања Краљевине СXC, које су биле обележене политичким сукобима, националним и културолошким супротностима, и економским проблемима, криза је достигла свој врхунац последњих месеци 1928. године. У таквој атмосфери створени су услови да краљ Александар I Карађорђевић преузме власт у своје руке. На Бадњи дан, 6. јануара 1929. године, краљ Александар I Карађорђевић је укинуо Видовдански устав, распустио Народну скупштину и завео диктатуру. Законом о називу и подели Краљевине на управна подручја, који је донет 3. октобра 1929. године, дотадашњи назив државе Краљевина Срба, Хрвата и Словенаца је промењен у Краљевина Југославија, док је државна територија подељена на девет управно-територијалних целина, бановина. ${ }^{1}$ На челу банске управе стајао је бан, представник врховне власти у бановини. Постављан је краљевим указом на предлог министра унутрашњих послова и уз сагласност Министарског савета. ${ }^{2}$ Као државни орган бан се старао о јавној безбедности и свим важнијим дешавањима у бановини, о чему је подносио појединачне и повремене

\footnotetext{
${ }^{1}$ Службене новине Краљевине Југославије, бр. 232, 4. октобар 1929.

${ }^{2}$ Милић Ф. Петровић, Државни родослов Кралевине Југославије/СХС 1918-1941, Београд $2008,153$.
} 
извештаје министру унутрашњих послова. ${ }^{3}$ Банска управа се делила на одељења, одсеке и одељке (реферате). Послови јавне безбедности у Дунавској бановини били су обухваћени II управним одељењем и његовим Одсеком за јавну безбедност. ${ }^{4}$

Бан је имао право да реорганизацијом одељења банске управе укида и успоставља одсеке. Његовим наређењем од 13. јула 1933. године Одсек јавне безбедности се поделио на два реферата. Први је био Реферат за јавну безбедност, у чију делатност је спадало старање о личној и имовинској безбедности, организовање аката службе за сузбијање криминалитета и хватање злочинаца, одржавање јавног реда и мира, старање о безбедности и реду јавног саобраћаја, жандармерија, контрола над радом полицијских власти, старање за усавршавање полицијске струке, као и за јединствено организовање полицијских власти и установа, старање о јединственом васпитању и одржавању дисциплине, старање о правилној примени Закона о држању и ношењу оружја, потерничка служба. Други је био Реферат за државну заштиту у чију надлежност је спадало старање о државној безбедности, сузбијање антидржавне пропаганде, полицијска обавештајна служба у Дунавској бановини, зборови и удружења, контрола штампе. Поред ова два реферата постојао је и Одељак за полицијски надзор над странцима и путничким саобраћајем. Одсек јавне безбедности је био самосталан одсек у обављању послова и налазио се под непосредном управом и надзором бана. ${ }^{5}$

Прописи о организацији полицијских установа унифицирани су за целу државу усвајањем Закона о унутрашњој управи 19. јуна 1929. године. Управа полиције је била државна месна полицијска установа у седишту бановине. На челу управе полиције је стајао управник полиције, који је био директно потчињен бану. Он је уједно био и референт бана за полицијске ствари општег значаја, као и за оне поједине послове полицијске природе који су му били поверени за подручје целе бановине. Управа полиције је имала право да доноси решења као државна месна полицијска власт првог степена. Жалбе на донета решења су се подносиле бану. Управа полиције се делила на одсеке, а они по потреби на реферате. На челу одсека стајали су шефови одсека који су били потчињени управнику полиције и одговарали су му за послове одсека. Они су вршили надзор над пословима одсека и реферата, делили су послове чиновницима, давали су им упутства о раду, старали су се о правилности, законитости и брзини рада одсека. Рефератима су управљали референти који су у погледу свог подручја рада имали исте дужности као и шефови одсека. За вршење целокупне канцеларијске службе управа полиције је имала потребан број канцеларијских службеника. Њихов рад је надзиран од стране шефа писарничке службе. ${ }^{6}$

Полицијски службеници су се делили на: полицијске стражаре и агенте, надзорне чиновнике полицијске страже и агената, заповедника полицијске страже и

\footnotetext{
${ }^{3}$ Закон о банској управи, Службене новине Краљевине Југославије, бр. 261, 7. новембар 1929.

${ }^{4}$ Службене новине Краљевине Југославије, бр. 250, 25. октобар 1929.

5 Архив Војводине, Фонд 126 Краљевска банска управа Дунавске бановине (даље: АВ, Ф 126), II 50565/1933, Наредба бана о подели рада у оквиру одсека јавне безбедности од 18. јула 1933.

${ }^{6}$ Уредба о устројству и делокругу Управа полиције, Службене новине Краљевине Југославије, бр. $62,18$. март 1930.
} 
шефа полицијских агената. ${ }^{7}$ За вршење полицијске егзекутивне службе на подручју управе полиције постојао је збор униформисане полицијске страже. Њему је у дужност спадало одржавање јавне безбедности, реда и мира. На челу му се налазио заповедник полицијске страже. ${ }^{8}$ За вршење полицијске „егзекутивне службе“ на подручју управе полиције постојао је и збор полицијских агената. Њихов посао се односио на вршење превентивног и репресивног деловања међу становништвом. Агенти су службу вршили у цивилним оделима. Агентима је заповедао шеф полицијских агената коме се додељивао потребан број надзорних чиновника. ${ }^{9}$

Бан је био надлежан да издаје потребне преписе који су регулисали: број и радна подручја одсека, реферата и писарничких јединица управе полиције; устројство и круг рада постојећих установа и потчињених органа, као и пријавница, затвора и економата; седишта полицијско-стражарских станица и граница њихових рејона; унутрашње уређење надлештава. На основу акта Министарства унутрашњих послова од 24. септембра 1924. године утврђивање броја полицијских стражара вршило се према броју становника. У градовима са преко 100.000 становника, на 1.000 становника долазила су по 4 полицијска стражара. У местима где се број становника кретао између 50.000-100.000 становника, на 1.000 становника долазила су по 3 полицијска стражара. У местима где се број становника кретао између 10.000-50.000 становника, на 1.000 становника долазила су по 2 полицијска стражара, а уколико су места мирна и без велике индустрије, чак и 1 стражар на 1.000 становника. У местима где се број становника кретао испод 10.000 становника, долазио је по 1-1 1/2 полицијски стражар. Број агената није улазио у горњи рачун, и био је у директној сразмери са постављеним задацима који су били различити за свако место. ${ }^{10}$

Уредбом о устројству и делокругу предстојништва градске полиције Министарство унутрашњих послова је организовало полицијске установе у великим градовима ван седишта бановина где се за тим показала потреба. На челу је био предстојник градске полиције који је вршио целокупан надзор на пословима предстојништва. Градови који су вршили општу управну власт првог степена, имали су предстојнике градске полиције који су били непосредно подређени бану. У осталим градовима предстојник градске полиције је обављао надлежне послове као овлашћени орган среског начелника под чијим надзором је био. ${ }^{11}$ Предстојништва градске полиције су установљена Уредбом од 4. новембра 1929. године на територији Дунавске бановине у следећим градовима: Великој Кикинди, Великом

\footnotetext{
7 Лаза М. Костић, Административно право, Устројство управе, књ. 1, Београд 1933, 172-176.

8 Заповедник полицијске страже се старао о дисциплини у збору, о прописаном снабдевању полицијских стражара службеним оделом, обућом, материјалом, оружјем и муницијом. Водио је рачуна о стручном усавршавању полицијских стражара, као и о уређењу касарни и станица.

${ }_{9}^{9}$ Шеф полицијских агената се старао да полицијски стражари-агенти, који су били додељени на службу квартовима управе полиције или полицијским комесаријатима, врше службу по наређењима дотичних старешина кварта, односно полицијског комесара.

${ }^{10}$ AВ, Ф 126/II 52286/1930, Допис о образовању државне полиције од 6. новембра 1929.

11 Уредба о устројству и делокругу предстојништва градске полиције, Службене новине Краљевине Југославије, бр. 243, 17. октобар 1929.
} 
Бечкереку, Вршцу, Крагујевцу, Сенти, Сомбору, Старој Кањижи, Суботици и Хоргошу. ${ }^{12}$ Предстојништво градске полиције делило се три на одељка: опште полиције, кривичне полиције и полиције места. У делокруг одељка опште полиције спадали су сви послови државне безбедности и јавног поретка, сузбијања шпијунаже, надзор над политичким и друштвеним животом, надзор над сумњивим лицима, надзор над штампом и зборовима, полицијска обавештајна служба и општа администрација (персоналне ствари). Одељак кривичне полиције водио је све послове полицијске природе и старао се о личној и имовинској безбедности грађана, а у вези са ислеђивањем кривичних дела и сарадње са судовима. Надлежности одељка полиције места биле су вршење казне власти по кажњивим делима из управног казненог закона, вршење казнене власти у извршењу наредби, надзор над јавним локалима и приредбама, надзор над извршењем обртних прописа, старање у погледу безбедности и реда јавног саобраћаја, вршење послова здравствене и ветеринарске полиције. ${ }^{13}$

Предстојник градске полиције примао је сву поверљиву пошту, старао се о организацији унутрашње и спољашње обавештајне службе, надзирао је рад канцеларијског и стражарског особља, давао је директиве свим референтима. Заменик предстојника (поткапетан) водио је кривично одељење, одељење здравствене полиције, надзор над кафанама и трговинама. Постојале су две врсте концеписта: први концеписта обављао је истражне ствари из делокруга полиције, док је други концеписта водио административну евиденцију. Рачунски чиновник (официјал) је обављао све послове који су били у вези са финансијама, водио је пасошко одељење, поступке око дозволе точења пића, издавао је дозволе за држање и ношење оружја. Агенти су се бавили пословима унутрашње и спољашње обавештајне службе, надзора над сумњивим лицима, надзора над страним лицима. Најнижи положај у оквиру предстојништва градске полиције имали су редари, писари и дневничари. ${ }^{14}$ Како би се обезбедило редовно пословање предстојништва градске полиције, општине су биле дужне да у свој буџет унесу потребан износ неопходан да буду обухваћене све принадлежности полицијског особља. ${ }^{15}$

На основу непотпуних података може се стећи слика о броју запослених чиновника у полицији. Према систематизацији предстојништва градске полиције из 1930. године ${ }^{16}$ на територији Дунавске бановине она су имала следећи број службеника:

\footnotetext{
${ }^{12}$ Све раније бивше полицијске установе у тим местима које су вршиле улогу месне полицијске власти престале су постојати 31. децембра 1929, Уредба о формирању предстојништва градске полиције, Службене новине Краљевине Југославије, бр. 266, 14. новембар 1929.

${ }_{13}$ AВ, Ф 126/II 8269/1935, Правилник о унутрашњем уређењу надлештава, о броју одељака, о подели на исте и о систематизацији броја особља код предстојника градских полиција у Дунавској бановини.

${ }^{14} \mathrm{AB}$, Ф 126/II 6342/1932, Предстојништво градске полиције Велике Кикинде - Градском начелству, 22. мај 1930.

${ }^{15}$ Поред тога, градска општина је била дужна да обезбеди потребне зграде и просторије за смештај предстојништва полиције. У случају да дође до спора у погледу обима обавеза које терете општину, арбитражу је вршио бан, а против његовог решења жалба се могла поднети надлежном министарству, Уредба о устројству и делокругу предстојништва градске полиције..

${ }^{16} \mathrm{AB}$, Ф 126/II 105606/1930.
} 


\begin{tabular}{|c|c|}
\hline Велика Кикинда & Крагујевац \\
\hline $\begin{array}{l}\text { предстојник градске полиције } \\
1 \text { полицијски пристав } \\
1 \text { полицијски приправник } \\
2 \text { манипулативна чиновника (официјал и } \\
\text { канцелариста) } \\
5 \text { званичника дневничара } \\
2 \text { агента } \\
1 \text { наредник } \\
35 \text { градских редара } \\
1 \text { послужитељ }\end{array}$ & $\begin{array}{l}\text { предстојник градске полиције } \\
3 \text { полицијска пристава } \\
1 \text { приправник } \\
1 \text { стални званичник } \\
6 \text { званичника дневничара } \\
1 \text { наредник } \\
40 \text { градских редара } \\
1 \text { послужитељ }\end{array}$ \\
\hline "Велики Бечкерек & Сомбор \\
\hline $\begin{array}{l}\text { предстојник градске полиције } \\
2 \text { полицијска пристава } \\
1 \text { полицијски приправник } \\
3 \text { манипулативна чиновника } \\
3 \text { манипулативна приправника } \\
1 \text { стални званичник дневничар } \\
6 \text { привремених дневничара } \\
4 \text { полицијска агента } \\
2 \text { наредника } \\
45 \text { градских редара } \\
6 \text { коњаника редара } \\
1 \text { послужитељ } \\
\end{array}$ & $\begin{array}{l}\text { предстојник градске полиције } \\
1 \text { виши полицијски пристав } \\
2 \text { полицијска пристава } \\
1 \text { полицијски приправник } \\
1 \text { надзорник полиције } \\
6 \text { сталних дневничара } \\
3 \text { привремена дневничара } \\
2 \text { полицијска агента } \\
3 \text { наредника } \\
35 \text { градских редара } \\
20 \text { редара коњаника } \\
1 \text { послужитељ } \\
\end{array}$ \\
\hline Вршац & Стара Кањижа \\
\hline $\begin{array}{l}\text { предстојник градске полиције } \\
1 \text { полицијски пристав } \\
4 \text { манипулативна чиновника } \\
4 \text { дневничара } \\
2 \text { полицијска агента } \\
1 \text { комесар } \\
3 \text { наредника } \\
45 \text { градских редара } \\
1 \text { послужитељ }\end{array}$ & $\begin{array}{l}\text { предстојник градске полиције } \\
1 \text { полицијски пристав } \\
1 \text { приправник } \\
1 \text { манипулативни чиновник } \\
1 \text { дневничар } \\
1 \text { полицијски агент } \\
1 \text { наредник } \\
15 \text { градских редара } \\
1 \text { послужитељ }\end{array}$ \\
\hline Сента & ב्Суботица \\
\hline $\begin{array}{l}\text { предстојник градске полиције } \\
2 \text { полицијска пристава } \\
3 \text { манипулативна чиновника } \\
6 \text { сталних дневничара } \\
2 \text { привремена дневничара } \\
2 \text { полицијска агента } \\
1 \text { наредник } \\
49 \text { градских редара } \\
1 \text { послужитељ }\end{array}$ & $\begin{array}{l}\text { предстојник градске полиције } \\
2 \text { виша полицијска пристава } \\
3 \text { полицијска пристава } \\
4 \text { манипулативна чиновника } \\
7 \text { званичника дневничара } \\
7 \text { надзорника полицијске страже } \\
13 \text { полицијских агената } \\
2 \text { наредника } \\
12 \text { водника } \\
146 \text { градских редара } \\
20 \text { редара коњаника } \\
2 \text { послужитеља }\end{array}$ \\
\hline
\end{tabular}


Чиновници ресора Министарства унутрашњих послова који су били распоређени код среских начелстава, среских испостава и државних месних полицијских власти морали су да носе службена одела. Чиновници су се међу собом

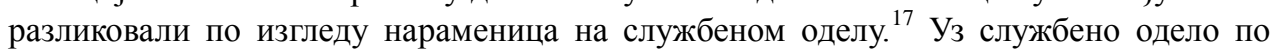
потреби се носио револвер. Приликом ношења службеног одела чиновици су били дужни да поздрављају салутирањем као војници. За куповину службеног одела чиновнике је следовао месечни додатак. ${ }^{18}$ Полицијски органи су се информисали преко Полицијског гласника који је штампан у облику листа и бесплатно им је достављан. Када полицијски органи приме гласник, његову садржину је одређени чиновник саопштавао свим осталим чиновницима, жандармима и агентима који су били одређени за истраживачко-обавештајну службу. ${ }^{19}$

Стање јавне безбедности на територији Дунавске бановине било је предмет сталног интересовања Министарства унутрашњих послова и Краљевске банске управе. Оне су реаговале када би дошло до погоршавања јавне безбедности и пораста криминалних дела. Током прве половине 1931. године у Дунавској бановини дошло је до пораста разбојништава, провала, крађа и убистава, приликом којих су истраге у већини случајева биле без резултата. Та чињеница је указивала надлежнима да је у органима јавне безбедности изостала енергична делатност у погледу превентивне службе јавне безбедности. Овакво стање је било резултат одсуства јаке и сталне контроле старешина над радом потчињених органа. Министарство је молило Краљевску банску управу да у споразуму са командом жандармеријског пука хитно предузме све што је било потребно да се јавна и лична безбедност грађана потпуно осигура. Једна од мера коју је требало предузети односила се на „перманентно“ патролирање општинских и жандармеријских патрола. Сумњива лица која су била склона вршењу криминалних дела требало је ставити под строги надзор. Ова мера се нарочито односила на „Цигане скитаче“, „стране поданике“, пијанице и нераднике. У оним случајевима где би се показала „лабавост и небрежање“ у извршавању наређења, требало је предузети строге законске мере против одговорних и њихових непосредних старешина. Министарство је на крају запретило да ће уколико изостане побољшање стања јавне безбедности, у Дунавској бановини доћи до замене ,појединих“ управно-полицијских и жандармеријских старешина енергичнијим и способнијим. ${ }^{20}$ Краљевска банска управа је скренула пажњу свим среским начелницима, предстојницима градских

\footnotetext{
${ }^{17}$ Нараменице на службеним оделима чиновника ресора Министарства унутрашњих послова разликовала су се према плетеницама: плетенице од три гајтана носили су окружни инспектори, а плетенице од четвороструког опруженог гајтана су носили срески начелници, управници полиције, шефови одељења Управе града Београда, чланови квартова, предстојници градске полиције и полицијски комесари, Правилник о службеном оделу за чиновнике ресора Министарства унутрашњих послова, Службени лист Дунавске бановине, бр. 5, 5. април 1931.

${ }_{18}$ Чиновници који су били дужни да носе свечано одело имали су право на новчани додатак у висини од 200 динара месечно. Остали чиновници су примали додатак у висини од 100 динара, Исто.

${ }_{19}^{19}$ Упут за састављање и издавање потерница и објава, Служсбени лист Дунавске бановине, бр. 18, 5. јул 1931.

${ }^{20}$ AВ, Ф 126/II 10844, Допис Министарства унутрашњих послова у вези са мерама за поправку јавне безбедности у Дунавској бановини од 15. априла 1931.
} 
полиција и Управи полиције Нови Сад на мере које је прописала поводом дописа Министарства унутрашњих послова. ${ }^{21}$

Полицијска служба је у међуратном периоду сматрана престижним занимањем, и за њу су били заинтересовани многобројни свршени гимназијалци, а неретко и они са универзитетским образовањем. Полицијски службеници, у једној недовољно просвећеној и бирократизованој земљи каква је била Краљевина Југославија, представљали су својеврсну елиту. Служба је са собом носила одређену моћ, и врло честа је била појава да су полицијски службеници самовољно подређивали себи сва дешавања и читав живот у местима где су службовали. Велики број полицијских службеника није утицао на ефикасност државне администрације, која је била спора због лоше организације и поделе посла, политичког уплитања и притисака, недовољне дисциплине и одсуства систематске контроле. ${ }^{22}$ Сталност у служби била је ретка, а чак је и приватни живот могао бити разлог за губљење посла. Честе промене места боравка и премештања, по награди или по казни, нису одговарали приватном животу, нити стварању чврстих социјалних веза. Политички обрачуни доводили су до премештања „по потреби службе“ више хиљада чиновника због припадности ривалским странкама. Политичка подобност била је последица уверења да су чиновници дужни да служе власти, док се о служби држави није много размишљало.

Пријем у полицијску службу вршио се преко конкурса на које су се позивала заинтересована лица. Конкурс за пријем службеника у државну полицијску стражу у Новом Саду, расписан од стране бана Дунавске бановине, имао је ограничавајући карактер јер су према њему могли бити примљени само кандидати са територије предратне Србије. ${ }^{23}$ Услови конкурса су били следећи: одслужен кадровски војни рок, завршених минимум 4 разреда основне школе, висина преко $170 \mathrm{~cm}$, кандидати нису смели бити ожењени и старији од 30 година. Првенство приликом избора имали су они кандидати који су завршили средњу школу, као и бивши подофицири војске и жандармерије. Приликом ступања у службу изабрани кандидати су се обавезивали да ће службу вршити најмање три и по године, да се за то време неће женити, нити ће тражити дозволу за женидбу, као и да ће служити у сваком месту где по потреби службе буду распоређени. По пријему у службу кандидати су бивали

\footnotetext{
${ }^{21}$ Ради заштите јавне безбедности Краљевска банска управа је прописала следеће мере: 1. старешине надлештава су биле дужне да што чешће организују повремене рације на својој територији; 2. беспосличари, скитнице, лутајуће Цигане и остала лица која немају занимање требало је свим полицијским средствима прогонити; 3. лица која су била пуштена из судских затвора, која су била озлоглашени делинквенти надлежне управно-полицијске власти требало је држати под сталном контролом; 4. лица која су се бавила „,торбарењем (дротари, качари, пенџераши)“ требало је подврћи легитимисању и контроли; 5. требало је проверити идентитет лица која су долазила под изговором занатског и трговачког пословања; 6. вашарским коцкарима је требало забранити рад по дневним пиајацама и другим скуповима. Полицијски органи имали су обавезу да строго воде рачуна о дужностима и пословима који су им били поверени. Све полицијске власти имале су да узајамно сарађују и помажу једна другој, АВ, Ф 126/II 31367, Мере за поправку јавне безбедности 22. април 1931.

22 Ивана Добривојевић, Под будним оком држсаве. Државни чиновници у Краљевини Југославији, Приватан живот код Срба у 20. веку (прир. Милан Ристовић), Београд 2007, 480-481.

${ }^{23}$ Политика, 9. август 1930.
} 
упућени у стручну школу полицијске страже у трајању од шест месеци. После положеног стручног испита били би унапређени према способностима за поднареднике, а касније за нареднике. ${ }^{24}$

Приликом вођења кадровске политике, морало се водити рачуна о политичкој користи коју је требало остварити премештањем полицијских службеника. Једна од главних замерки опозиције у Војводини односила се на довођење „Србијанаца“ на места среских и полицијских начелника. На ово се гледало као на колонизаторску меру од стране београдских владајућих кругова, због чега је бан Дунавске бановине на тај проблем указивао председнику владе. ${ }^{25}$ Забележен је и случај да Министарство унутрашњих послова није могло да пронађе адекватно кадровско решење за место начелника Управе полиције у Новом Саду. ${ }^{26}$ Она је остала без начелника у децембру 1935. године, а то место остало је упражњено целу прву половину 1936. године. Дужност начелника обављао је један чиновник VII групе, иначе шеф кривичног одсека. Овај чиновник је био млађи по годинама и без довољно искуства, недостајао му је ауторитет према грађанству и потчињеном му чиновништву. То је био повод за различите интриге и зависти шефова других одсека. Поред тога што је под својом ингеренцијом имао Управу града са 70.000 становника, начелник је био и полицијски референт бана за територију целе бановине. Такво стање је трајало преко шест месеци и довело је до проблема у функционисању полицијске службе, због чега је бан ургирао код владе предлажући свог кандидата. ${ }^{27}$

Стварањем Краљевине Југославије, послови унутрашње безбедности били концентрисани у Министарству полиције. ${ }^{28}$ Закон о заштити јавне безбедности и

\footnotetext{
${ }^{24}$ Месечна плата стражара служитеља износила је 750 динара, а стражара званичника 950 динара, при чему им је следовала бесплатна одећа, обућа и стан у касарни, Исто.

${ }^{25}$ Током једне од великих ротација среских начелника у целој Краљевини Југославији, бан Светислав Пауновић је доставио своје мишљење о неким решењима која му је предложио председник владе. Између осталих, за Корнела Путника, комесара железничке и пограничне полиције у Суботици, који је био предложен за место предстојника градске полиције у Сомбору, захтевао је да остане на месту у Суботици јер га је било тешко заменити. Премештај би дошао у обзир само ако му се пронађе достојна замена, Архив Југославије, Фонд Милана Стојадиновића (даље: АЈ, Ф 37), 48-311-554.

${ }_{26}$ Управе полиције су образоване владином уредбом од 22. марта 1930. у главним местима свих девет бановина. Надлежност Управе полиције Новог Сада се простирала на територији града Новог Сада, општине Каменице и добровољачког насеља Ветерник, В. Манкин, Алманах Краљевине Југославије, 19.

${ }^{27}$ Из тог разлога бан Светислав Пауновић је захтевао да се ово место хитно попуни, тако што је предлагао др Светозара Стричевића, среског начелника у Осијеку, којег је лично познавао и гарантовао за његову стручност. Међутим, после састанка са управником града Београда Миланом Аћимовићем прихватио је као његов предлог Животу Симића, шефа политичког одсека Управе града Београда, АЈ, Ф 37, 48-311-554. ${ }^{28}$ Оно је било подељено на два сектора: Дирекцију јавне безбедности и Дирекцију националне безбедности.

Друга дирекција је задатке државне безбедности извршавала кроз три одељења: Политичко, Специјалнообавештајно и Одељење специјалне безбедности.

Политичко одељење је, заправо, било центар тајне полиције Краљевине Југославије, из кога се руководило контролом и сузбијањем активности странака и њихових присталица. Оно је водило истраге против ухапшених лица и предавало их државном тужиоцу. У свом саставу Политичко одељење је имало политички одсек за обавештајну службу, одсек за удружења и одсек за контролу штампе и штампарију. Ово одељење је било срж политичке полиције и зато је било најјаче у Краљевини Југославији, јер је
} 
поретка у држави и Закон о Државном суду за заштиту државе дали су политичкој полицији Краљевине Југославије изузетна овлашћења у прогону критичара режима династије Карађорђевић. Једно од главних обележја рада полиције у Краљевини Југославији било је сакупљање информација о планирању пучева, завера, субверзивних и шпијунских активности. Акценат на овакву делатност полиције одредио је њен главни задатак који се односио на заштиту државе. Овакво полицијско деловање у највећем броју случајева погађало је „мале људе“, тј. лица која нису намеравала да узму учешћа у некој од антидржавних радњи. Како је страх, оправдан или неоправдан, државе од сопствених поданика, као и страх грађана од државе, већи у ауторитативним режимима, то су могућности претераног сумњичења, злоупотреба и надзора већи. У несигурном међународном окружењу, држава је осећала обавезу да буде на сталном опрезу како према унутрашњим тако и према спољним непријатељима. Полицијски званичници од Министарства унутрашњих послова до општинског нивоа били су задужени за надзор и контролу свих политичких манифестација, при чему је полицијски надзор представљао и ,тековину“ парламентаризма. ${ }^{29}$

Сложена безбедоносна ситуација на територији Дунавске бановине била је условљена односом власти према бројним националним мањинама. Тај однос је посебно долазио до изражаја на северу бановине, где су Немци и Мађари били већинско становништво. Органи безбедности имали су главну улогу у спровођењу забране употребе матерњег језика у службеном општењу са властима, као и у спречавању могућности за политичко деловање и организовање. Поред овога, припадници националних мањина били су изложени и физичком насиљу које је ишло од пребијања до повремене употребе ватреног оружја од стране полицијских службеника. Истовремено је полиција пружала заштиту различитим југословенским националистичким удружењима у њиховим обрачунима са неистомишљеницима. Сваки вид јавног изражавања незадовољства од стране националних мањина у Дунавској бановини за собом је повлачио репресију у виду цензуре штампе и укидања културноуметничких и других друштава. ${ }^{30}$ Полицијско насиље је нарочито

покривало територију читаве земље.

Специјално-обавештајно одељење руководило је контраобавештајним пословима југословенске тајне полиције, који су били подељени у пет реферата: бугарско-албански, мађарски, италијански, немачки и за остале државе.

Обавештајна и Контраобавештајна служба, при полицији, имале су првенствени задатак да сакупљају податке и да се супротстављају деловању страних тајних служби како унутар Југославије, у дипломатским, привредним и војним представништвима, тако и напољу, пре свега да делују против агената из Мађарске, Аустрије, Италије и Бугарске. Одељење специјалне безбедности старало се о евидентирању свих особа чија је активност била битна за сам режим, као и о вршењу аналитичких послова у тајној служби. У одсецима на терену формирани су и посебни досијеи за праћена лица, чије су копије обавезно морале да се шаљу за Београд, где је основана Централна картотека југословенске политичке полиције.

${ }^{29}$ Надзор над државним чиновницима, губитак службе због сепаратизма или комунизма, денунцирање, суђења због увреде краља или краљевског дома, жандармеријска насиља, изборни терор, надзирање обичних људи су биле најчешће злоупотребе у периоду 1919. до 1941. године, Ивана Добривојевић, Државна репресија у доба диктатуре краља Александра 1929-1935, Београд 2006, 163-164.

30 Зоран Јањетовић, Деца ияарева, пасторчад краљева, Београд 2005, 446-448. 
било интензивно приликом избора или током предизборне кампање. Југословенске власти у међуратном периоду нису имале поверење у припаднике националних мањина и оне су биле изложене сталном надзору полицијских органа. У свим званичним извештајима среских и полицијских начелника догађаји везани за припаднике националних мањина посебно су наглашавани. ${ }^{31}$ Државни национализам у грубљој или блажој форми спровођен је од стране припадника органа безбедности, што је код припадника националних мањина изазивало огорченост. ${ }^{32}$

Стварањем Краљевине Југославије ударени су и нови темељи југословенског обавештајно-безбедносног система, у којем је жандармерија представљала окосницу унутрашње и јавне безбедности. Жандармерија је истовремено била помоћни род војске и специјална трупа. Са полицијом је била основни носилац државне власти, док се војска употребљавала само у изузетним случајевима. ${ }^{33}$ Налоге у погледу вршења службе одржавања јавног реда, мира и безбедности жандармерија је могла примати искључиво од службених власти, којима је подносила извештаје. Уредбом од 26. фебруара 1919. године образована је јединствена жандармерија за целу земљу. ${ }^{34}$ Команда целокупне жандармерије је била административни орган II степена. Жандармерија је у погледу снабдевања, дисциплине и војне наставе била потчињена министру војном, а у погледу употребе, наставе, одржавања јавне безбедности и жандармеријске службе министру унутрашњих послова. Формација жандармерије је бројала 10.000 људи, њена команда се налазила у Београду на челу са командантом жандармерије који је био у рангу команданта дивизије. Краљевом уредбом од 17. децембра 1923. године установљено је девет жандармеријских пукова и два самостална жандармеријска батаљона. ${ }^{35}$ Пукови су се делили на чете, чете на водове а водови на сталне и привремене жандармеријске станице. Према подацима из 1941. године, у жандармерији су службовала 732 официра и 18.151 жандарм. ${ }^{36}$

Седиште жандармеријског пука Дунавске бановине било је у Новом Саду. Формацијски пук се делио на чете које су носиле називе по месту становања или по броју. Жандармеријска чета се делила на водове по местима становања, сваки срез је требало да има по један вод. Жандармеријски водови су се делили на сталне и привремене жандармеријске станице које су могле бити пешадијске, коњичке, велосипедске и мешовите. Жандармеријским станицама су командовали подофицири и каплари. Жандармеријски официрски кадар попуњавао се из редова

\footnotetext{
${ }^{31}$ АВ, Ф 126/II 21144/1930, Двомесечни извештаји КБУ Дунавске бановине упућени од стране среских и полицијских начелника за 1930. и 1931. годину.

32 3. Јањетовић, Нав. дело.

${ }^{33}$ Миле Бјелајац, Војска Краљевине Срба, Хрвата и Словенаца 1918-1921, Београд 1988, 73-74.

${ }^{34}$ Наредба о формацији, опреми, поднадлежности, дужностима и опреми жандармерије, Служббени новине Краљевине СХС, бр. 16, 1919.

35 Десети пук је формиран 1930. године под називом Београдски жандармеријски пук, а после успостављања Бановине Хрватске 1939. године формирана је и жандармеријска бригада Бановине Хрватске, М. Ф. Петровић, Држсавни родослов, 222.

${ }^{36}$ Војна енииклопедија, књ. 4, Београд 1961, 239.
} 
активних официра, редовних официра и неожењених жандармеријских наредника који су били млађи од 30 година. ${ }^{37}$ Служба у жандармерији се обнављала на сваке три године, али је након десет година могла да постане стална. Припадници жандармерије могли су да напусте службу у сваком тренутку. ${ }^{38}$

Припадници жандармерије су током вршења службе често прекорачивали своја овлашћења. Законом о жандармерији из 1922. године било је предвиђено да жандармеријски старешина при гушењу нереда начин деловања може одредити према властитом нахођењу. ${ }^{39}$ То је био разлог за учестале жалбе које су грађани упућивали бану. Због тога је Краљевска банска управа Дунавске бановине издала наређење по коме је жандаремерији наложено да у додиру са грађанима не показује грубост. Непожељним се сматрало испољавање „субјективности, личне воље, напраситости, неучтивости и немарности“. Већи резултати у контакту са народом требало је да се постигну „озбиљним“ и „хладним“ вршењем дужности, „,коректним“ и „тихим“ опхођењем према грађанима, као и „општом сталоженошћу“. Нарочита пажња је требало исказати према „женском свету“. Како би се ово наређење спровело, бан је захтевао да све старешине најенергичније и што чешће контролишу рад потчињених им органа. Са оним припадницима жандармерије који су у служби показивали немар, грубост и несавесност, требало је „рашчистити“. ${ }^{40}$ Слично бану је поступило и Минстарство унутрашњих послова јасно прописивши крајњу обазривост жандарма у опхођењу са народом, да се њиховим поступцима „народ не би раздражио“ и стао на страну кривца. Међутим, у стварности ова наређења се нису поштовала, батинања и понижавања ухапшених била су свакодневна. Ухапшеници су третирани као лица чија је кривица била доказана самим чином хапшења. Оваква жалосна пракса је била резултат слабог културног нивоа жандарма, менталитета, осећаја моћи, али и својеврсне традиције и наслеђа. Незадовољство грубостима жандармерије постојало је константно током целог периода постојања југословенске краљевине. ${ }^{41}$

Пријаве жандарма за малтретирање су редовно провераване, али је ретко када било шта могло бити и доказано. Велики скандал је избио када су припадници жандармерије претукли немачку новинарку из Великог Бечкерека Хилду Изолду Рајтер 15. маја 1930. године. Неколико дана касније жандармерија је ухапсила и адвоката Вилхелма Нојнера, бившег народног посланика. Они су били оптужени за активности које су за циљ имале присаједињење Баната Мађарској или Румунији. ${ }^{42}$ Поводом поступка према немачкој новинарки бечка штампа је писала да је „Ројтерова мучена на барбарски начин јер је она Немица“ и да „само Срби на овакав начин кажњавају оне који припадају једној мањини, а тако се иначе у Европи не

\footnotetext{
${ }^{37}$ М. Ф. Петровић, Нав. дело, 223-225.

38 Л. М. Костић, Административно право, 389-390.

${ }^{39}$ Војна енциклопедија, књ. 10, Београд 1967, 810.

${ }^{40}$ AB, Ф126/II 93536/1930.

41 Владан Јовановић, Жандарми и практиканти, Образовање код Срба кроз векове (ур. Радослав Петковић, Петар В. Крестић, Тибор Живковић), Београд 2003, 200-204.

${ }^{42}$ Zoran Janjetović, ,Die Konflikte zwischen Serben und Donauschwaben, Suedost-Forschungen 58, $1999,140$.
} 
усуђује кажњавати ни најобичнијег злочинца“ ${ }^{43}$ Како нису располагале са довољно доказа, власти су након интервенције немачког посланства у Београду оптужене пустиле на слободу. Југословенске власти су покушале да негирају тортуру над оптуженицима, али су на крају признале да је новинарка мучена. Одговорни за ово злостављање су били отпуштени, ,,али су нашли службу у другим надлештвима“. ${ }^{44}$

Својом бројношћу жандармерија је отварала могућност да велики број њених припадника прекорачи своја законска овлашћења. Држава је имала задатак да се стара о свим случајевима где су се та прекорачења догодила и да реагује казнама за починиоце. Власти су преко свега тога олако прелазиле, при чему се није водило рачуна да је народ судио о држави према поступцима њених званичних представника са којима је непосредно долазио у додир. Државу су у народу најчешће представљали срески начелници и припадници жандармерије, због чега је незадовољство народа највећим делом било уперено против њих, а не против државних институција.

Ради школовања жандармеријског кадра, 1. фебруара 1920. године је у Сремској Каменици формирана Жандармеријска подофицирска школа. Школа је била смештена у згради бивше Краљевске и царске пешадијске кадетске школе Аустроугарске монархије. ${ }^{45}$

\footnotetext{
${ }^{43}$ И. Добривојевић, Државна репресија..., 182.

${ }^{44}$ Исто.

45 Зграда у којој се налазила Жандармеријска подофицирска школа саграђена је средином 19. века, на земљишту каменичког властелина Марцибанија, које је поклонио за потребе школовања војних кадета Аустријске царевине, под управом Петроварадинске војне команде. Школа је већ крајем 1869. године била распуштена и зграда је дуго била празна. Потом је у њој била фабрика свиле и Војарна за финанце 43. и 70. пешадијске пуковније. Године 1895. основана је Краљевска и царска пешадијска кадетска школа. Тада почиње и веће уређење простора око школе, гради се школска капела, павиљон и велики обелиск на улазу у зграду, у част аустроугарског цара, а уређује се и парк око школе.

Жандармеријска подофицирска школа Краљевине СХС/Југославије је постојала све до почетка Другог светског рата. У то време са зграде школе се уклањају све ознаке аустроугарског царства. Зграда припада код нас мало сачуваном стилу романтизма и спада у највеће објекте на територији општине Нови Сад. Пројектант за сада није познат. Планови свих војних школа зиданих у време Аустријске царевине, па тако и школе у Каменици, налазе се у Бечу. Све су сличног изгледа и зидане тако да у потпуности одговарају намени (војном школовању), а осим о архитектури, водило се рачуна и о самом положају школе, о географском локалитету, изграђеној инфраструктури и о близини главних путева, железнице и града.

Данас је у овој згради смештен Центар за основну полицијску обуку Министарства унутрашњих послова Републике Србије, Весна Ковачевић, ,Зграда стара век и по, Млади полицајац 54-55, Сремска Каменица 2009, 4-6.
} 


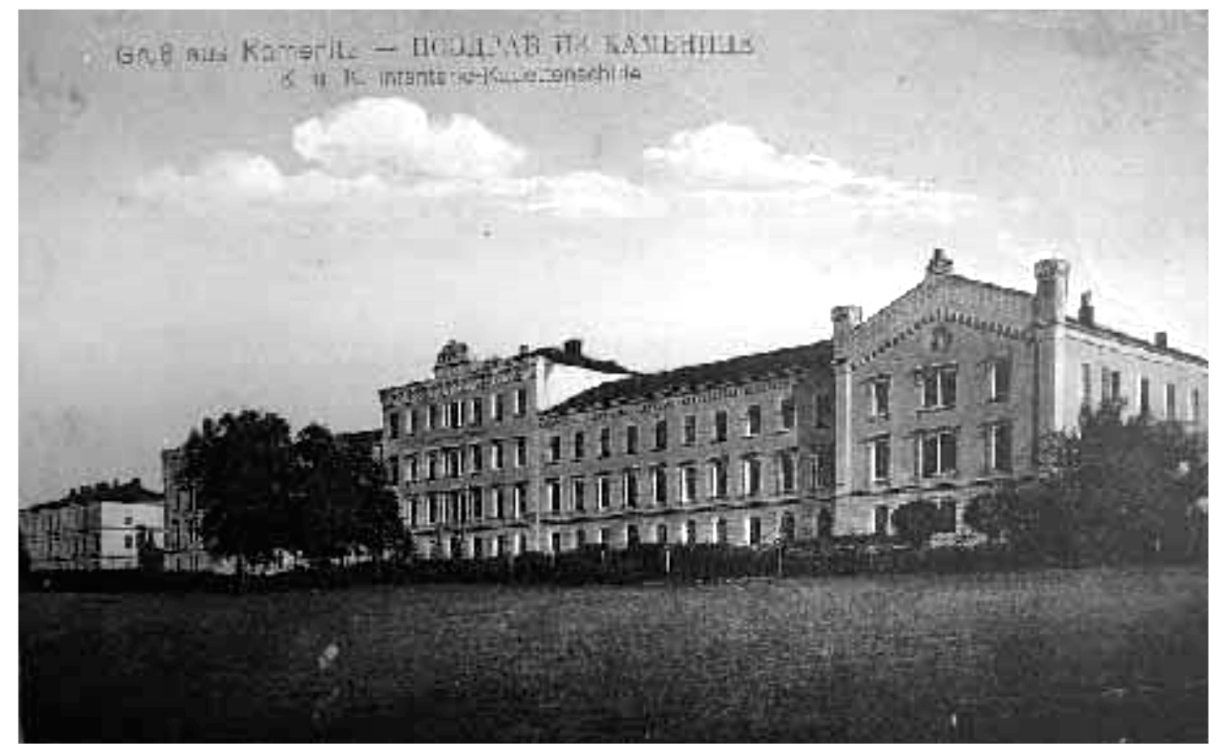

Зграда Жандармеријске подофицирске школе у Сремској Каменици

На страницама штампе остала је забележена свечаност приређена приликом завршетка школовања последње класе у Жандармеријској подофицирској школи Кральевине Југославије. Крај пколовања поцразумево је полагање завршних испита којима су присуствовали председник владе Драгиша Цветковић, министар унутрашњих послова Станоје Михалџиһ и бан Дунавске бановине Бранко Кијурина. У кругу школе било је постројено 435 питомаца, испред којих се налазила испитна комисија. Комисијом је председавао командант жандармерије генерал Милутин Стефановиһ. После завршетка испита уручене су награде пајбољима у класи и одржан је дефиле питомаца. Председник владе је затим разгледао државно одгојилипте паса који се дресирају за потребе жандармеријске службе. Гости су том приликом обишли лепо уређени криминални музеј, учионице, просторије у којима је уређиван Жандармеријски весник, библиотеку која је била опремљена многим страним стручним часописима. ${ }^{46}$

Завођење Шестојануарске диктатуре и формирање бановина као административних јединица донело је организационе промене у оквирима јавне безбедности. Краљ Александар I Карађорђевић је имао потпуну подрпку у спровођењу своје политике једино у редовима полиције и војске. У таквим околностима велике обавезе прешле су на бана, који је био извршни орган владе и

\footnotetext{
46 Председник владе Драгиша Цветковиһ је на крају посете Жандармеријској подофицирској школи изразио своје највеће задовољство радом, дисциплином и уређењем на које је наишао у овој школи, као и наставом која је дала одличне резултате. Све то је, по њему, укупно резултовало да жандарми извршавају у потпуности свој задатак, како у војничком тако и у погледу остале службе безбедности, Дан, 17. мај 1940 .
} 
Министарства унутрашњих послова, одговоран за спровођење донетих одлука у дело. Поред редовних полицијских органа, бан је имао контролу и над радом жандармерије, мада она de facto није била у надлежности бановинске управе. Безбедоносну ситуацију у Дунавској бановини додатно је компликовао њен географски положај и састав становништва. Срески начелници у Дунавској бановини у највећем броју случајева били су носиоци организације полицијске службе у повереним им срезовима. Од њиховог става и воље зависило је много тога, што се одражавало и на понашање нижих органа власти укључујући полицију и жандармерију, код чијих припадника је постојао стални страх од губитка сигурне и релативно добро плаћене државне службе. Полиција и жандармерија су у очима становништва Дунавске бановине биле симбол власти, режима и саме државе. Главни разлог нерасположења становништва према жандармерији треба тражити у чињеници да је она редовно пратила пореске извршитеље приликом присилне наплате пореза, што је врло често доводило до отворених сукоба становништва и државних органа. Приликом обављања својих задатака припадници безбедоносних органа свесно су излазили из оквира правила службе, што је било повезано са степеном репресије којем су и они сами били изложени од стране централних управних органа. Стање у општој безбедности у Дунавској бановини се није разликовало од оног какво је било на нивоу целокупне територије Краљевине Југославије, а оно се могло оценити као задовољавајуће. 


\title{
PUBLIC SAFETY AND LAW ENFORCEMENT IN THE DANUBE BANOVINA
}

\begin{abstract}
Summary
This work examines the public safety and law enforcement system of the Danube Banovina, allowing insight into prevailing conditions throughout the Kingdom of Yugoslavia. Particular attention is paid to the relationship of law enforcement officers towards citizens and members of the ethnic minorities. Officer compliance with duties was frequently contingent on pressures from the central administration. Sources for this research include the holdings of the Royal Administration of the Danube Banovina belonging to the Archives of Vojvodina, as well as the Official Gazette of the Kingdom of Yugoslavia.
\end{abstract}

Keywords: public safety and law enforcement, organisation of law enforcement agencies, law enforcement officers, municipal police, police service, security situation, gendarmerie, police repression. 